\title{
Variable Reduction and Determinants of Working Capital Management on Profits for Ghanaian Banks
}

\author{
Abeku Atta Asare-Kumi \\ Kwasi Adjepong Darkwah \\ Ezekiel Nii Noye Nortey \\ Charlotte Chapman-Wardy
}

Department of Statistics, University of Ghana, Legon

doi: 10.19044/esj.2016.v12n7p316 URL:http://dx.doi.org/10.19044/esj.2016.v12n7p316

\begin{abstract}
Today, several factors has contributed to the profitability of Banks. Data collected on these factors often has several variables. It is a non-trivial exercise to determine which of the factors that significantly influences the profits of Banks. This paper adopts the use of Principal Component Analysis (PCA) on the several variables expected to influence the working capital management on the profits of banks of the Ghana Stock Exchange (GSE). Fifteen of the several variables captured by the GSE which affect working capital management on profit were grouped into four factors using the principal component analysis. Results of the PCA identifies Convertibility factors, Risk Factor, Short term Liquidity, Operational factors, and Credit Risk factors to be the determinants of bank profits. Consequently, these factors are used to fit a linear regression model in identifying the most significant factors. Apart from credit risk factors, all the other factors were found to be significant predictors of the profit of Ghanaian banks. Investors, stakeholders, and managers of banks can use these factors to monitor and evaluate their working capital in generating profits.
\end{abstract}

Keywords: Working Capital Management, Principal Component Analysis, Linear Regression

\section{Introduction}

The management of working capital in any industry or business is a well thoughtful effort that cannot be over-emphasized. Kaur (2010) defined Working Capital Management as the administrative activities and decisions that have an effect on the size and efficacy of the working capital. The author explained further that management of current liabilities, current assets, and the association that exists between them constitute working capital 
management. Over the years, the major concern of financial analysts and economists is the measurement of the association between working capital management and profit. However, the ratios of working capital management and cash flows are factors that affect the association of working capital. The term "cash" is made up of firm's cheques and balances, currencies, and coins in their banks account. Thus, fund differ in the sense that, it is a broader term than cash. Several companies define funds as working capital, which is having more current assets than currents liabilities. In view of this, working capital can be defined as the availability of cash for the daily running of banks. It is therefore expedient for banks to ensure effective working capital since shortage may slow down banking activities. On the other hand, excessive working capital may not result in favorable profits. Hence, there is the need for effective management of bank's working capital in order to ensure a stable and satisfactory working capital.

The main aim of this study is to examine the factors that affect the management of working capital on the profits of banks of the Ghana Stock Exchange (GSE), and to extract a smaller number of variables from a larger set using Principal Component Analysis (PCA). Thus, the study employed eight variables for principal component analysis. These are Debt Collection Period (DCP), Creditors Payment Period (CPP), Bank Size (SIZE), Cash Conversion Cycle (CCC), Leverage (TDA), Bank Growth (GR), Exchange Rate Risk (ERR), and Risk (RISK).

According to Jolliffe (2002), the main aim of the Principal Component Analysis (PCA) is to minimize the dimensionality of a data set. This data set is made up of a large number of variables that are interrelated while withholding the variability available in the data set.

\section{Literature review and conceptual frame work}

Eljelly (2004) sampled from the joint stock companies in Saudi Arabia and used correlation and regression analysis to examine current ratio and cash conversion cycle. This was done by assessing the association between liquidity and profitability. However, Eljelly found that current ratio has lesser effect on liquidity as compared to cash conversion cycle that affect profitability.

Deloof (2003) also examined the association between working capital management and profitability. Thus, he found that a significant negative association existed between gross operating income and inventories, the number of accounts receivable and accounts payable days of Belgian firms using regression tests and correlation. He recommended that managers should reduce their inventories and accounts receivable days in order to create value for their shareholders. The negative association between accounts payable and profitability, supported the conclusion of Raheman and 
Nasr (2007). Thus, the conclusion states that firms which yield less profits often experience delay in the payment of their bills.

Machiraju (2001) defined working capital management as the management of the current assets and the current liabilities of a firm. Van Horne (2000) is of the view that the management of working capital has to do with how a firm manages its current assets in the form of cash, receivables, market securities, and inventories. Thus, the association between a firm's short-term assets and its short-term liabilities constitute the management of working capital. In view of this, Khan and Jain (2007) stated that the problems that one encounter when managing the current assets, current liabilities, and the association between them constitutes working capital management.

In banks, such short term expenses may differ from other firms because of the peculiarity in the nature of business. Beside other day-to-day expenses, banks are expected to meet depositors' demand of withdrawal. This therefore means that working capital management in banks aim to ensure that the banks are able to continue their operations by having sufficient cash flow to satisfy both maturing short-term debt and upcoming operational expenses.

Demirgüç-Kunt and Detragianche (1998) examined the effect of banking environment and its characteristics on the margins of interest rate and bank returns using data on 80 countries for the period of 1988-1995. Therefore, their findings suggest that regulatory and macroeconomic conditions have an effect on margins and profitability.

Using a dynamic panel model, Athanasoglou et al. (2005) researched the performance of Greek banks over the period 1985-2001. Also, they concluded that there is an imperfect competition in the market structure due to consistency in profit.

Deloof (2003) sampled 1,009 large Belgian non-financial firms for a period of 1992-1996. Furthermore, he used regression and correlation to investigate the relationship between working capital and corporate profitability. The study identified a significant negative association between gross operating income and the Cash Conversion Cycles of Belgian firms.

Lazaridis and Tryfonidis (2006) sampled 131 firms listed on the Athens Stock Exchange for the period of 2001-2004. They used regression to analyze the correlation between working capital management and corporate profitability. In addition, they identified a significant correlation between profitability and the cash conversion cycle.

Samiloglu and Demirgunes (2008) also ascertained that inventory period, receivables period, and leverage have a negative significant effect on the profit, while firm growth (in sales) have a positive effect on the profit of Turkish manufacturing firms. They sampled 5, 843 Turkish listed 
manufacturing companies for the period of 1998- 2007, and used multiple regression model to analyze the impact of working capital management on profit.

The findings of Falope and Ajilore (2009) in their study using a pooled regression on a sample of 50 Nigerians quoted non-financial firms for the period of 1996-2005 where cross-sectional and time-series observations were estimated, revealed a significant negative correlation between cash conversion cycle and net operating profitability.

\section{Materials and Methods}

Audited annual financial reports collected from 10 Banks listed on Ghana Stock Exchange (GSE), over a period of eight years from 2006-2015, were used in the study.

Fifteen independent variables that were expected to have an effect on working capital management on profits of banks were also selected for the study (Agyei \& Yeboah, 2011; Yeboah \& Yeboah, 2014). The variables, the categories they belong to, and their definition are shown in Table 1 below. Thus, the variables are grouped under five main categories to represent the firm's convertibility of assets into cash, operating asset efficiency, short term liquidity and movement of Debtors and Creditors, the policy of the firm, and Risk (Arunkumar and Radharamanan, 2013; Nortey et al., 2016).

Table 1. Variables Description

\begin{tabular}{|c|c|c|}
\hline Types of Variable & Category & Definition \\
\hline $\begin{array}{l}\text { 1.Cash Conversion Cycle } \\
\text { (CCC) }\end{array}$ & Short term liquidity & $\begin{array}{l}\text { The difference between } \\
\text { debtors collection period } \\
\text { and creditors payment. }\end{array}$ \\
\hline $\begin{array}{l}\text { 2.Debtors Collection } \\
\text { Period (DCP) }\end{array}$ & Policy factor & $\begin{array}{c}\text { The ratio of bank } \\
\text { current assets to interest } \\
\text { income in } 365 \text {. }\end{array}$ \\
\hline $\begin{array}{l}\text { 3. Creditors Payment } \\
\text { Period (CPP) }\end{array}$ & Policy factor & $\begin{array}{l}\text { The ratio of bank short- } \\
\text { term debt to interest } \\
\text { expense in } 365 .\end{array}$ \\
\hline 4.Bank Size ( SIZE) & Convertibility factor & $\begin{array}{l}\text { Natural logarithm of } \\
\text { total assets. }\end{array}$ \\
\hline 5.Leverage(TDA) & Operational factor & $\begin{array}{l}\text { The ratio of total debt to } \\
\text { total net assets. }\end{array}$ \\
\hline 6.Risk (RISK) & Risk factor & $\begin{array}{l}\text { Standard deviation of } \\
\text { profitability. }\end{array}$ \\
\hline $\begin{array}{l}\text { 7.Bank Growth } \\
\text { (GROWTH) }\end{array}$ & Short term liquidity & $\begin{array}{l}\text { Year on year change in } \\
\text { interest income between } \\
\text { current years. }\end{array}$ \\
\hline $\begin{array}{l}\text { 8.Exchange Rate } \\
\text { Risk (ERR) }\end{array}$ & Risk factor & $\begin{array}{c}\text { Annual Standard } \\
\text { Deviation of Official }\end{array}$ \\
\hline 9.Current Ratio (CR) & Convertibility factor & Exchange rate \\
\hline 10.Quick Ratio (QR) & Short term Liquidity & The ratio of current to \\
\hline $\begin{array}{l}\text { 11. Current Assets to Total } \\
\text { Assets (CATA) }\end{array}$ & Convertibility factor & $\begin{array}{l}\text { current liabilities. } \\
\text { It measures how a }\end{array}$ \\
\hline 12.Current Liabilities to & Convertibility factor & company meets its \\
\hline
\end{tabular}


Total Assets (CLTA)

13.Credit Risk (CRISK)

14. Cash Flow (CF)

15.Current Assets to Total Sales
Risk factor

Short term liquidity

Convertibility factor short-term obligations with its most liquid assets.

The ratio of current assets to total assets.

The risk that some borrowers may not be able to pay the principal and its associated interest when due.

The ratio of current liabilities to total assets. It is the net amount of cash and cashequivalents moving into and out of a bank.

The ratio of current assets to total sales.

\section{Principal Component Analysis (PCA)}

Principal components are those linear combinations $X_{1}, X_{2}, \ldots, X_{P}$ which are not correlated, and whose variances $\operatorname{Var}\left(X_{i}\right)=b_{i}^{\prime} \sum b_{i}, i=1,2, \ldots, p$ are as large as possible. Given $\operatorname{Cov}\left(\mathrm{X}_{i}, \mathrm{X}_{k}\right)=b_{i}^{\prime} \sum b_{k}, i, k=1,2, \ldots, \mathrm{p}$, where $b_{i}^{\prime}=b_{i 1}, b_{i 2}, \ldots, b_{i p}$ are the weights, then:

$b_{i}^{\prime} \cdot b_{i}=1$ $b_{i}^{\prime} \cdot b_{j}=0$ for all $i \neq j$

The first principal component is the linear combination $b_{1} X$ that maximizes $\operatorname{Var}\left(\mathrm{b}_{1}^{\prime} X\right)$ subject to $b_{1}^{\prime} b_{1}=1$. However, this accounts for the greatest variance in the data. The second principal component is also a linear combination $b_{2}^{\prime} X$ that maximizes $\operatorname{Var}\left(b_{2}^{\prime} X\right)$ subject to which $b_{2}^{\prime} b_{2}=1$ and $\operatorname{Cov}\left(b_{1}^{\prime} X, b_{2}^{\prime} X\right)=0$. However, this accounts for the greatest of the remaining variance in the data and so on. The number of variables in the data set is reduced for the interpretation or analysis of the correlation among the variables when the first principal component caters for a greater portion of the variance in the original data (Johnson and Wichern, 2007).

Suppose each of the bank's financial statements is an observed variable $Y_{1}, \mathrm{Y}_{2}, \ldots, \mathrm{Y}_{p}$ with weights $b_{i j}, i=1,2, \ldots, p, j=1,2, \ldots, p$, then the principal component $X_{1}, X_{2}, \ldots, X_{P}$ are given by: 


$$
\begin{gathered}
X_{1}=b_{11} y_{1}+b_{12} y_{2}+\ldots+b_{1 p} y_{p} \\
X_{2}=b_{21} y_{1}+b_{22} y_{2}+\ldots+b_{2 p} y_{p} \\
\vdots \\
X_{P}=b_{k 1} y_{1}+b_{k 2} y_{2}+\ldots+b_{k p} y_{p}
\end{gathered}
$$

Let the random variable $Y_{i}(i=1,2, \ldots, \mathrm{p})$ have mean $\mu_{i}$ and the standard deviation $\sigma_{i i}$. Thus, the transformed standard variables $Z_{i}(i=1,2, \ldots, \mathrm{p})$ is given as:

$$
Z_{i}=\frac{Y_{i}-\mu_{i}}{\sigma_{i i}}
$$

Furthermore, the vector of the standardized variables could be written in matrix notation as:

$$
Z=\left(V^{1 / 2}\right)^{-1}(\mathrm{Y}-\mu)
$$

where $\mu^{\prime}=\left(\mu_{1}, \mu_{2}, \ldots, \mu_{k}\right)$ and $\mathrm{V}^{1 / 2}$ is the diagonal standard deviation matrix given by:

$$
\begin{aligned}
& V^{1 / 2}=\left[\begin{array}{cccc}
\sigma_{i i} & 0 & \cdots & 0 \\
0 & \sigma_{22} & \cdots & 0 \\
\vdots & \vdots & \ddots & \vdots \\
0 & 0 & \ldots & \sigma_{k k}
\end{array}\right] \\
& E\left[Z_{i}\right]=0, \operatorname{Var}\left[Z_{i}\right]=1, i=1,2, \ldots, \mathrm{k} \text { and } \operatorname{Cov}(\mathrm{Z})=\left(\mathrm{V}^{1 / 2}\right)^{-1} \sum\left(\mathrm{V}^{1 / 2}\right)^{-1}=\rho
\end{aligned}
$$

where the variance-covariance matrix $\sum$ and the correlation matrix $\rho$ of $Y$ are given by:

$$
\begin{aligned}
& \sum=\left[\begin{array}{cccc}
\sigma_{11}^{2} & \sigma_{12}^{2} & \cdots & \sigma_{1 k}^{2} \\
\sigma_{21}^{2} & \sigma_{22}^{2} & \ldots & \sigma_{2 k}^{2} \\
\vdots & \vdots & \ddots & \vdots \\
\sigma_{k 1}^{2} & \sigma_{k 2}^{2} & \ldots & \sigma_{k k}^{2}
\end{array}\right] \\
& \rho=\left[\begin{array}{cccc}
1 & \frac{\sigma_{12}^{2}}{\sigma_{11} \sigma_{22}} & \cdots & \frac{\sigma_{1 k}^{2}}{\sigma_{11} \sigma_{k k}} \\
\frac{\sigma_{12}^{2}}{\sigma_{11} \sigma_{22}} & 1 & \cdots & \frac{\sigma_{2 k}^{2}}{\sigma_{22} \sigma_{k k}} \\
\vdots & \vdots & \ddots & \vdots \\
\frac{\sigma_{1 k}^{2}}{\sigma_{11} \sigma_{k k}} & \frac{\sigma_{2 k}^{2}}{\sigma_{22} \sigma_{k k}} & \cdots & 1
\end{array}\right]
\end{aligned}
$$


And

$\rho_{i j}=\frac{\sum_{k=1}^{n}\left(\mathrm{y}_{k i}-\mu_{i}\right)\left(\mathrm{y}_{k j}-\mu_{j}\right)}{n}, i \neq j$ is the covariance between variables $Y_{i}$ and $Y_{j}$, each of which has $n$ observations.

The $p$ principal components $\mathrm{X}^{\prime}=\left[X_{1}, \mathrm{X}_{2}, \ldots, \mathrm{X}_{p}\right]$ are derived from the eigenvectors of the correlation matrix of $\rho$ of $Y$ given by: $X=B^{\prime} Z$

where $B=\left[e_{1}, e_{2}, \ldots, e_{k}\right]$ and the $e_{i} s, i=1,2, \ldots, k$ are the eigenvectors of $\rho$.

The eigenvalue -eigenvector pairs $\left(\lambda_{1}, e_{1}\right),\left(\lambda_{2}, e_{2}\right), \ldots,\left(\lambda_{k}, e_{k}\right)$ of $\rho$ are such that

$$
\begin{aligned}
& \lambda_{1} \geq \lambda_{2} \geq \ldots \geq \lambda_{k} \geq 0, e_{i}^{\prime} \cdot e_{i}=1 \text { and } e_{i}^{\prime} \cdot e_{j}=0, \\
& \operatorname{Var}\left(\mathrm{X}_{i}\right)=e_{i}^{\prime} \rho e_{i}=\lambda_{i} \\
& \text { And } \\
& \sum_{i=1}^{k} \operatorname{Var}\left(\mathrm{X}_{i}\right)=\sum_{i=1}^{k} \operatorname{Var}\left(Z_{i}\right)=P
\end{aligned}
$$

Subsequently, the proportion of the total variance in the data which is explained by the $X_{j}$ is given by the proportion $\frac{\lambda_{j}}{p}$. This is called communality.

Where $j=1,2, \ldots$, pand the $\lambda_{j}{ }^{\prime} s$ are the eigenvalues of $\rho$.

The loading of the standardized variable $Z_{j}$ which is a correlation between each principal component $X_{i}$ and its corresponding standardized variable $Z_{j}$ is given by:

$$
\operatorname{Corr}\left(\mathrm{X}_{i}, Z_{j}\right)=e_{i j} \cdot \lambda_{j}^{(1 / 2)}
$$

Where the loading of the standardized variable $Z_{j}$ is between -1 and 1 inclusive.

Therefore, this shows the degree to which every $Z_{j}$ affects every $X_{i}$ which is conditioned on the influence of the other variables $Z_{m}, j \neq m$ (Johnson and Wichern, 2007). The variable becomes more influential in naming and interpreting the component when there is a higher absolute value of a loading of a variable on a component. Also, the size of the sample determines the significance of the magnitude of a loading. A loading of an absolute value of at least 0.30 and 0.35 with respective sample sizes of 350 
and 250 is suggested by Hair et al. (2006). This shows that a smaller sample size requires a greater absolute loading values. Sharma (1996) recommended a loading of magnitude which is more than or equal to 0.50 .

However, the principal component being used as an index involves the establishment of principal component scores and factor loadings. The principal component scores which is the $i^{t h}$ principal component is derived by putting the standardized observed values of the variables into the equation as shown below:

$$
X_{i}=e_{i}^{\prime} Z
$$

The number of observed variables being examined is the same as the number of components derived in the principal component analysis. This is because only the first few components account for a greater amount of the variance in the original data. Thus, these few components are sustained, interpreted, and are involved in subsequent analysis.

The principal component analysis is used because the main aim of the study is to acquire a smaller number of factors that can explain the greatest variability that exist in the observed variables.

However, the extraction and the significance of factors depend on factors with eigenvalues that is greater than 1 . The value 1 is the SPSS default setting Kaiser stopping criterion for selecting the number of factors to be extracted.

The Kaiser-Meyer- Olkin (KMO) statistic which measures sampling adequacy is employed. Therefore, if the value is greater than or equal to 0.5 , the sample is regarded to be adequate. Also, when the probability value of Bartlett's Test of Sphericity is less than the significance level, the principal component analysis can be used for the analysis. The magnitude of the factor loadings, communalities, or sampling adequacy measures are used for making decisions irrespective of the sign of its value. However, this is because the sign determines the direction of the association. The plus (+) and minus (-) signs indicate a direct and inverse relationship respectively.

Principal Component Analysis (PCA) will be used to examine the 8 variables that affect working capital management of the profits of banks in reducing variables that are interrelated in order to acquire variables that are not correlated. Rotation of the factors is used for helping in the interpretation of analysis. Consequently, the amount of variance and factors extracted are not affected by the rotation of the factors.

The orthogonal rotation method called Varimax will be used since our main objective is to reduce the variables that affect working capital management on the profits of banks. The variability of the squared loadings is maximized on all the variables in the matrix that contains only the factors. 
The impact of these factors extracted using Principal Component Analysis (PCA) on profit is analyzed using regression analysis. It is used to project to the extent a unit change, in each factor extracted using Principal Component, has on profitability. Hence, this is modelled using the following general regression equation: $Y_{i t}=\alpha_{0}+\sum_{\text {all }}^{n} \beta_{i} X_{i t}+\varepsilon_{i t}$

Where $Y_{i t}=$ Profitability of firm $i$ at time $t$.

$\alpha_{0}=$ The intercept of the equation

$\beta_{i}=$ Coefficient of $X_{i t}$

$X_{i t}=$ Independent variable of firm $i$ at time $t$

$t=$ time from $1,2, \ldots, 10$ years (from year 2006 to 2015)

$\varepsilon_{i t}=$ The error term

\section{Linear Regression}

Linear regression attempts to model the relationship between a dependent variable and a set of independent variables by fitting a linear equation to observed data. One variable is considered to be a dependent variable, while the other(s) is/are considered to be an independent variable(s). Thus, this is the study of linear, additive relationships between variables. When only one independent variable exists, a Simple Linear Regression is the most appropriate in explaining the relationship between the two variables. When a scatter plot of the two variables shows a clustering of points close to a straight line, a linear relationship is said to exist between the two variables.

A simple linear regression model is of the form;

$$
Y_{i}=\beta_{o}+\beta_{1} X_{i}+\varepsilon_{i}
$$

Where $Y_{i}$ and $X_{i}$ are the response and independent variables, respectively.

$\beta_{o}$ and $\beta_{1}$ are the regression parameters to be estimated, and $\varepsilon_{i}$ is the random error.

A line that best fits the data is one for which the prediction errors are as small as possible in some overall sense. Thus, one way to achieve this goal is to adopt the least squares criterion, which minimizes the sum of the squared prediction errors. minimize.

Hence, $\quad \beta_{o}$ and $\beta_{1}$ are estimated by $b_{o}$ and $b_{1}$ such that they

$$
Q=\sum_{i=1}^{n}\left(y_{i}-\hat{y}_{i}\right)^{2}
$$


The estimated model is therefore given by:

$$
\hat{y}_{i}=b_{o}+b_{1} X_{i}
$$

Subsequently, where there are more than one independent variable, the model that best explains the relationship is referred to as the multiple linear regression model. The multiple linear regression model is of the form:

$$
Y_{i}=\beta_{o}+\beta_{1} X_{1}+\beta_{2} X_{i}+\cdots+\beta_{p} X_{p}+\varepsilon_{i}
$$

Where $Y_{i}, X_{1}, X_{2}, \ldots, X_{p}$ are the response and $\mathrm{p}$ - independent variables, respectively.

$\beta_{o}, \beta_{1}, \ldots, \beta_{p-1}$ are the regression parameters to be estimated by the method of least squares, and $\varepsilon_{i}$ is the random error.

The regression model assumes that a linear relationship exists between the dependent and independent variables. It also assumes that the random error component are independent and identically distributed as normal with mean zero $(0)$ and variance $\sigma^{2}$.

For more on regression analysis, correlation, and coefficient of determination, refer to the study of Montgomery, Peck and Vining (2012) and Weisberg (2005).

\section{Findings and Discussions} Summary Statistics

The Summary statistics of 10 banks over a period of 8 years for the mean, the standard deviation, skewness, and kurtosis for all the variables that have an effect on working capital management on profit is shown in Table 2 below.

Table 2. Summary Statistics

\begin{tabular}{cccccc}
\hline Variables & $\mathrm{N}$ & Mean & S.D & Skewness & Kurtosis \\
\hline ROA & 100 & 0.166770 & 0.595396 & 3.886 & 27.890 \\
SIZE & 100 & 29.95830 & 32.443495 & 1.451 & 0.715 \\
CCC & 100 & 83.67860 & 27.145268 & 2.949 & 15.180 \\
DCP & 100 & 98.91900 & 15.050338 & 1.134 & 2.576 \\
TDA & 100 & 99.83430 & 25.958365 & -0.180 & 1.454 \\
CPP & 100 & 69.99130 & 16.406486 & 1.658 & 1.333 \\
RISK & 100 & 2.764670 & 1.2781725 & -0.284 & -0.807 \\
ERR & 100 & 0.390170 & 0.1452950 & 1.196 & -0.509 \\
CRISK & 100 & 11.54670 & 5.2068889 & 1.825 & 4.523 \\
CR & 100 & 0.545320 & 0.1430800 & 1.124 & 1.923 \\
CLTA & 100 & 0.161020 & 0.0334504 & -0.403 & 0.589 \\
CF & 100 & 0.390310 & 0.2346711 & 4.621 & 23.578 \\
QR & 100 & 2.73270 & 1.100090 & 0.384 & -0.565 \\
GR & 100 & 0.385020 & 0.1612966 & -0.070 & -0.566 \\
CATS & 100 & 0.152600 & 0.043707 & 0.141 & 0.529 \\
CATA & 100 & 0.190980 & 0.0674057 & 1.067 & 1.581 \\
\hline
\end{tabular}




\section{Principal Component Results}

This part shows the results of the principal component analysis. The P-value of Kaiser-Meyer -Olkin was 0.657, indicating that the sample adequacy was good. The Bartlett's Test of Sphericity was significant at 0.00 , showing that the Principal Component Analysis (PCA) can be performed on the data.

The Communalities of each variable is shown in Table 3. This indicates that the extracted factors accounts for the variability in the variables. For instance, over $94.9 \%$ of the variance in CR is explained and accounted for, while over $91.7 \%$ of the variance in RISK is also explained and accounted for.

Table 3. The Communalities of the Variables

\begin{tabular}{cccccc}
\hline Variables & CR & RISK & GR & TDA & CRISK \\
\hline Initial & 1.000 & 1.000 & 1.000 & 1.000 & 1.000 \\
Extraction & 0.949 & 0.917 & 0.771 & 0.757 & 0.680 \\
\hline
\end{tabular}

The eigenvalues showing the importance of each of the 15 principal components is found in Table 4. The first five eigenvalues are above 1.00 which explains over $71.548 \%$ of the total variance in the data. Therefore, we can conclude that five factor solution will be adequate.

Table 4. Total Variance Explained

\begin{tabular}{cccc}
\hline Component & & $\begin{array}{c}\text { \% Variance of Initial } \\
\text { Eigen values }\end{array}$ & $\begin{array}{c}\text { Cumulative \% of Initial } \\
\text { Eigen }\end{array}$ \\
\hline 1 & 4.317 & 28.779 & 28.779 \\
2 & 2.429 & 16.193 & 44.972 \\
3 & 1.604 & 10.692 & 55.664 \\
4 & 1.354 & 9.028 & 64.692 \\
5 & 1.028 & 6.856 & 71.548 \\
6 & 0.945 & 6.301 & 77.849 \\
7 & 0.818 & 5.455 & 83.304 \\
8 & 0.702 & 4.678 & 87.982 \\
9 & 0.581 & 3.876 & 91.858 \\
10 & 0.438 & 2.923 & 94.780 \\
11 & 0.361 & 2.409 & 97.190 \\
12 & 0.258 & 1.718 & 98.908 \\
13 & 0.091 & 0.605 & 99.513 \\
14 & 0.048 & 0.318 & 99.831 \\
15 & 0.025 & 0.169 & 100.000 \\
\hline
\end{tabular}

However, the factor loadings result from Varimax rotation of the 8 independent variables that affect working capital management on profits of banks is shown in Table 5 below. 
Table 5. Rotated Component Matrix

\begin{tabular}{cccccc}
\hline Factors & 1 & 2 & 3 & 4 & 5 \\
\hline CATS & 0.271 & 0.615 & 0.275 & 0.090 & 0.186 \\
SIZE & -0.163 & -0.108 & -0.795 & 0.210 & 0.015 \\
CCC & 0.005 & -0.105 & -0.158 & 0.102 & -0.605 \\
DCP & 0.144 & -0.250 & -0.045 & 0.669 & 0.000 \\
TDA & -0.053 & 0.213 & 0.120 & $\mathbf{0 . 8 3 1}$ & -0.069 \\
CPP & 0.939 & 0.216 & 0.076 & 0.071 & -0.008 \\
CATA & 0.954 & -0.038 & 0.005 & -0.024 & 0.035 \\
ERR & 0.028 & 0.243 & 0.762 & -0.270 & 0.08 \\
RISK & 0.018 & $\mathbf{0 . 9 2 9}$ & 0.206 & -0.095 & 0.048 \\
CR & $\mathbf{0 . 9 6 3}$ & 0.110 & 0.078 & 0.053 & 0.025 \\
CLTA & 0.228 & 0.219 & 0.463 & -0.321 & 0.471 \\
CF & 0.343 & 0.268 & 0.221 & -0.198 & 0.370 \\
GR & -0.046 & 0.148 & $\mathbf{0 . 8 3 4}$ & 0.056 & 0.219 \\
CRISK & -0.057 & -0.182 & -0.190 & 0.426 & $\mathbf{0 . 6 5 3}$ \\
QR & 0.097 & 0.888 & 0.102 & -0.044 & -0.010 \\
\hline
\end{tabular}

However, the SPSS results of the selected variables, their factor loadings, and the categories they belong to after using the Principal Component Analysis and Varimax as the rotation method are shown in Table 6 below. The variables are categorized into five factors, namely: Policy factor, convertibility factor, and operational factor.

Table 6. Selected Variables after Factor Analysis

\begin{tabular}{|c|c|c|c|c|}
\hline Factor & Variables & Code & $\begin{array}{l}\text { Factor } \\
\text { Loading }\end{array}$ & Category \\
\hline 1 & $\begin{array}{c}\text { Current } \\
\text { Ratio }\end{array}$ & $\mathrm{CR}$ & 0.963 & Convertibility factor \\
\hline 2 & Risk & RISK & 0.929 & Risk Factor \\
\hline 3 & Bank & GROWTH & 0.834 & Short term Liquidity \\
\hline 4 & $\begin{array}{l}\text { Growth } \\
\text { Leverage }\end{array}$ & TDA & 0.831 & Operational factor \\
\hline 5 & Credit Risk & CREDITRISK & 0.653 & Credit Risk Factor \\
\hline
\end{tabular}

\section{Multiple Regression Analysis}

The impact of the factors extracted using principal component analysis on profit was modelled and estimated using multiple regression technique given as:

$$
R O A_{i t}=\beta_{0}+\beta_{1} C R_{i t}+\beta_{2} \operatorname{RISK}_{i t}+\beta_{3} \text { RROWTH }_{i t}+\beta_{4} T D A_{i t}+\beta_{5} \text { CREDITRISK }_{i t}+\varepsilon_{i t}
$$

Durbin Watson (D-W) and Variance Inflation Factor (VIF) statistics was analyzed to check for the presence of autocorrelation and multicollinearity in the data, respectively. It is clear from Table 8 that the statistics are within the limit which make us conclude that there is no autocorrelation and multicollinearity in the data. Therefore, the highest value of VIF statistics acquired is 1.204. According to literature, VIF's of 10 or higher became a concern to researchers (Gujarati \& Sangeetha, 2008). D-W 
statistics value was found to be 1.112 for the multiple regression model. Durbin-Watson statistic ranges in value from 0 to 4 with a value of 1.111 indicating that the errors are not correlated and the $\mathrm{D}-\mathrm{W}$ is considered acceptable (Makori and Jagongo, 2013). D-W value indicating no collinearity was considered by Makridakis and Wheelwright (1978) to be between 1.5 and 2.5 .

Table 7. Multiple Linear Regression Results

\begin{tabular}{cccccc}
\hline Parameter & Coefficient & t-value & Sign. & Tolerance & VIF \\
\hline Constant & 0.167 & 0.365 & 0.716 & & \\
CR & -1.114 & -2.097 & $0.039^{* *}$ & 0.976 & 1.025 \\
RISK & 0.304 & 4.710 & $0.000^{* * *}$ & 0.831 & 1.204 \\
GR & 2.065 & 4.149 & $0.000^{* * *}$ & 0.874 & 1.144 \\
TDA & -0.006 & -2.052 & $0.043 * *$ & 0.958 & 1.044 \\
CRISK & -0.011 & -0.732 & 0.466 & 0.939 & 1.065 \\
\hline$*, * *$, and *** denotes significance level at $10 \%, 5 \%$ \& $1 \%$ levels, respectively. \\
\end{tabular}

From Table 8, the regression equation is given as:

$$
R O A_{i t}=0.405-1.114 C R_{i t}+0.304 R I S K_{i t}+2.065 R_{i t}-0.006 T D A_{i t}-0.006 C R I S K_{i t}+\varepsilon_{i t}
$$

The regression results in Table 8 indicates that the coefficient of CR is negative with -0.011 ( $\mathrm{p}$-value $=0.039$ ). Subsequently, this shows that $\mathrm{CR}$ is not statistically significant at $1 \%$ level of significance. In addition, this suggests that, despite the fact that CR is good for explaining the progress in the finances of the listed banks in Ghana Stock Exchange, it is not an important factor to consider when making critical decisions to increase profitability. An increase in Return on Assets increases GR and RISK, but decreases with leverage (TDA). The CRISK which is a theoretical measure of risk has no significant effect on the profits of the listed banks in Ghana Stock Exchange.

Furthermore, the overall multiple linear regression is statistically significant. This is shown with F-value of $12.763(\mathrm{p}<0.001)$. The model's adjusted $R^{2}$ of 0.404 shows that $40.4 \%$ of the differences in a firm's profit can be explained by the model.

\section{Conclusion}

There are several internal and external factors that affect working capital management on the profits of banks. The aim of the study is to use principal component analysis to analyse the interrelationship among the independent variables and to obtain a smaller set of variables from the many variables that affect working capital management on the profits of banks with a minimum loss of information. The principal component analysis is applied on 15 selected variables from 10 banks listed on the Ghana Stock Exchange. Investors, policy holders, or managers of banks can use the 
factors extracted using principal component analysis to monitor and evaluate their working capital to produce profits.

In conclusion, the results of the variables that affect working capital management on the profits of banks can be grouped into four factors. Hence, at least, operational, short term liquidity, and risk factors are chosen to represent the variables that affect working capital management on the profits of banks after the principal component analysis.

Finally, this paper is limited to studies or research conducted in Ghana on the selection and usage of the most important variables when analyzing the variables that affect working capital management on the profits of banks. It will also contribute to knowledge in Ghana and Africa as a whole since there are only few researches conducted using principal component analysis to extract factors from several variables that affect working capital.

\section{References:}

Agyei \& Yeboah (2011). Working Capital Management and Profitability of Banks in Ghana. British Journal of Economics, Finance and Management Sciences, Vol. 2 (2).

Arunkumar \& Radharamanan (2013). Variables Affecting Working Capital Management of Indian Manufacturing Firms: Factor Analysis Approach. International Journal of Financial Management, vol 3 Issue 2.

Athanasoglou, Brissimis \& Delis (2005). Bank-Specific, Industry- Specific and Macroeconomic Determinants of Bank Profitability.

Deloof (2003). Does working capital management affect profitability of Belgian firms? Journal of Business Finance and Accounting, 30(3\&4), 573587.

Demirguc-Kunt and Detragianche (1998) The determinants of Banking Crises in Developing and Developed Countries, International Monetary Fund, Vol. 45, No. 1, pp. $81-109$.

Eljelly (2004). Liquidity-Profitability tradeoff:An empirical investigation in an emerging market. International Journal of Commerce \& Management, Vol 14:48-61.

Falope \& Ajilore (2009). Working capital management and corporate profitability: evidence from panel data analysis of selected quoted companies in Nigeria. Research Journal of Business Management, 3, 73-84.

Hair et al. (2006). Multivariate Data Analysis. 6th ed. Pearson Prentice Hall, Upper Saddle River, New Jersey, USA.

Johnson \& Wichern (2007).Applied multivariate statistical analysis. USA: Pearson Education, Inc.

Jolliffe (2002). Principal Component Analysis, Second Edition. Springer. 
Kaur (2010). Working capital management in Indian Tyre industry. International Research Journal of Finance and Economics, (46), 7-15.

Khan \& Jain (2007). Financial Management. Tax, Problems and Cases. (5th ed.). Tata, MC Graw: Hill Publishing Company Limited.

Lazaridis \& Tryfonidis (2006). Relationship between working capital management and profitability of listed companies in the Athens stock exchange. Journal of Financial Management and Analysis, 19(1), 26-35.

Machiraju (2001). Introduction to Project Finance and an Analytical Perspective. Vikas.

Montgomery, Peck, and Vining (2012). Introduction to Linear Regression Analysis, 5th Edition. Wiley

Nortey, Darkwah, Asare-Kumi and Iddi (2016). 'Determinants of Working Capital Management on Profit for Manufacturing Firms',The International Journal of Business\& Management. Vol 4,Issue 1, pp.302-308.

Raheman \& Nasr (2007). 'Working capital management and profitability case of Pakistani firms', International Review of Business Research Papers.

Samiloglu \& Demirgunes (2008), 'The effect of working capital management on firm Profitability: Evidence from Turkey', The Int. J. Applied Econ. Finance, 2: 44-50.

Sharma (1996). Applied Multivariate Techniques. John Wiley and Sons, Inc., USA.

Van Horne (2000). Fundamentals of financial management, (11th Ed.). Prentice Hall Inc.

Weisberg (2005), Applied Linear Regression, Third Edition. Wiley Series in Probability and Statistics

Yeboah \& Yeboah (2014). The Effect of Working Capital Management of Ghana Banks on Profitability: Panel Approach. International Journal of Business and Social Science, Vol.5, N0.10. 